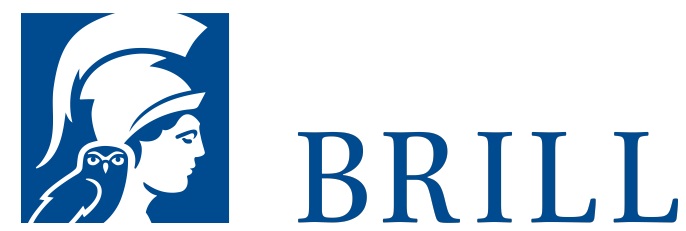

\title{
The Medieval Chronicle 11
}

\section{Volume Editors: Erik S. Kooper and Sjoerd Levelt}

Alongside annals, chronicles were the main genre of historical writing in the Middle Ages. Their significance as sources for the study of medieval history and culture is today widely recognised not only by historians, but also by students of medieval literature and linguistics and by art historians. The series The Medieval Chronicle aims to provide a representative survey of the on-going research in the field of chronicle studies, illustrated by examples from specific chronicles from a wide variety of countries, periods and cultural backgrounds.

There are several reasons why the chronicle is particularly suited as the topic of a yearbook. In the first place there is its ubiquity: all over Europe and throughout the Middle Ages chronicles were written, both in Latin and in the vernacular, and not only in Europe but also in the countries neighbouring on it, like those of the Arabic world. Secondly, all chronicles raise such questions as by whom, for whom, or for what purpose were they written, how do they reconstruct the past, what determined the choice of verse or prose, or what kind of literary influences are discernable in them. Finally, many chronicles have been beautifully illuminated, and the relation between text and image leads to a wholly different set of questions.

The Medieval Chronicle is published in cooperation with the Medieval Chronicle Society...

See More

\section{Readership}

All papers included will be both of interest and accessible to scholars from any disciplinary background who share a common interest in the medieval chronicle, or more generally medieval historiography.

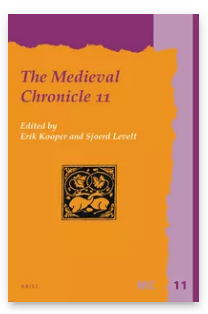

Pages: $308 \mathrm{pp}$.

Language:

English

Subjects:

Medieval

History, History,

Criticism \&

Theory,

Literature and

Cultural Studies,

History of

Warfare, History

Publisher: Brill

Series:

The Medieval

Chronicle,

Volume: 11

E-Book (PDF)

Released online:

20 Mar 2018

ISBN: 978-90-

04-35187-5

List price

USDP $\$ 95.5^{\circ}$

Paperback

Publication date:

og Nov 2017

ISBN: $978-90-$

o4-34158-6

List price

USD $\$ 95.5^{\circ}$ 
Erik Kooper received both his MA and Ph.D. degrees from Utrecht University, where he taught Old and Middle English until his retirement in 2007. Since then he has regularly taught courses and given guest lectures both at his own university, the Nijmegen Radboud University, and abroad. His recent publications include an edition of the Middle English poem Arthur (2011), and several articles, mostly on Middle English historiographical texts.

Sjoerd Levelt is Assistant Professor at the Program in Cultures, Civilizations and Ideas at Bilkent University, Ankara. He studied Dutch and English Medieval Studies in Amsterdam, Berkeley and Oxford, received his Ph.D. in Combined Historical Studies at the Warburg Institute, and previously taught at the Universities of Exeter and Sussex. He is a fellow of the Royal Historical Society and was awarded the Society for Renaissance Studies Book Prize 2012.

For more information see brill.com

$$
\begin{aligned}
& \text { Order information: Order online at brill.com } \\
& \text { +44 } 330333 \text { 0049 | customerservices@brill.com } \\
& \text { Submission information: brill.com/authors }
\end{aligned}
$$

Titles published by Brill | Fink, Brill | mentis or Brill | Schöningh: +49(o)71 5413279216 | brill@brocom.de 